\title{
Direct Determination of Silver in Uranium-Zirconium- Based Metallic Fuel Using GFAAS: An Insight Into the Effect of Matrix on the Atomization of Silver
}

\author{
Santosh Kumar Gupta, S.K. Thulasidas, Neelam Goyal*, and S.V. Godbole \\ Radiochemistry Division, Bhabha Atomic Research Centre, \\ Trombay, Mumbai 400 085, India
}

\section{INTRODUCTION}

In developing countries such as India energy demand is quite high. A thermal reactor can generate only limited amounts of energy because of limited ' $U$ ' reserves. This can, however, be achieved by the effective use of the limited resources of ' $U$ ' and employing fast breeder reactors (FBRs). The prototype fast breeder reactor (PFBR) will use mixed oxide fuel with $21 \%$ and $28 \%$ $\mathrm{PuO}_{2}$ as the driver fuel. However, future FBRs will utilize metallic fuel because of its higher thermal conductivity, high breeding potential ( 1.5-1.6), low doubling time ( $\sim 9$ years), and better safety features (1-12). The problem with metallic fuel is its low solidus temperature and high swelling rate. These issues could be overcome by choosing suitable alloy additions such as V, Nb, Mo, Zr, etc (13). Of all of these elements, zirconium was found to be the most suitable, and most of the work on metal fuel was carried out with U-Pu-Zr or U$\mathrm{Zr}$ alloy. The role of $\mathrm{Zr}$ is as follows:

- Increases the solidus temperature,

- Helps in overcoming the fuel clad chemical interaction,

- Linear heating rate of the fuel could be increased.

The addition of $\mathrm{ZrO}_{2}$ to the ceramic material is based on the expected enhancement in chemical stability and radiation resistance (14). All of the ceramic compositions have shown superior durabil-

\footnotetext{
* Corresponding autbor.

E-mail: neelam@barc.gov.in
}

\section{ABSTRACT}

Atomization of silver in a $\mathrm{U}+\mathrm{Zr}$ matrix was studied and the effect of $\mathrm{Zr} / \mathrm{U}+\mathrm{Zr}$ composition of the matrix on analyte absorbance was investigated. The changes observed in the absorbance signals for the analyte with a change in composition of the $\mathrm{U}+\mathrm{Zr}$ matrix are correlated to the relative oxygen partial pressures of $\mathrm{UO}_{2}$ and $\mathrm{ZrO}_{2}$. In these studies the direct determination of trace levels of silver in a $\mathrm{U}+\mathrm{Zr}$ matrix containing $20 \% \mathrm{Zr}$ was performed by graphite furnace atomic absorption spectrometry (GFAAS), resulting in a relative precision of approximately $\pm 10 \%$.

The method was also evaluated by analyzing synthetic $\mathrm{U}+\mathrm{Zr}$ samples and the results agreed favorably with the added contents. It is of significance to note that the present method gains in importance due to its ability to determine silver without the need of prior chemical separation of the $\mathrm{U}+\mathrm{Zr}$ matrix. The analytical procedure developed can be applied to the rapid analyses of fast breeder reactor (FBR) sample solutions without pre-treatment of the samples such as separation and pre-concentration of the matrix.

ity to their zirconia-free counterparts (15). Strict quality control on the purity of these materials has to be assured during the fuel fabrication process. The sodium-bonded $\mathrm{U}-\mathrm{Pu}-\mathrm{Zr}$ ternary alloy is the proposed fuel for advanced FBRs.

The determination of impurities in $\mathrm{U}$ and $\mathrm{Zr}$ at the various stages of the nuclear fuel cycle plays an important role in quality control and achievement of chemical and metallurgical requirements.

Because impurities such as B, Cd, and certain rare earths elements (such as Gd and $\mathrm{Sm}$ ) are strong neutron absorbers, their concentration in nuclear fuel has to be maintained below certain limits. Increased concentrations of impurities may alter the metallurgical characteristics of the $\mathrm{U}+\mathrm{Zr}$ fuel as well as the compatibility of the fuel with the reactor components. Silver is one such element to be monitored in the fuel. It has a high neutron absorption cross-section ( 91 barns for ${ }^{109} \mathrm{Ag}$ ). Since India uses the closed fuel cycle, depleted uranium from spent fuel after reprocessing is going to be used in the fast breeder reactor. Despite the low fission yield of the stable ${ }^{109} \mathrm{Ag}(0.03 \%$ for $\left.{ }^{235} \mathrm{U}\right)$ and its low conversion rate of $0.1 \%$ to ${ }^{110 \mathrm{~m}} \mathrm{Ag}$ by neutron capture, the latter is considered one of the key fission products. Total Ag concentration, therefore, should be monitored in FBR fuel since its isotope of ${ }^{110 \mathrm{~m}} \mathrm{Ag}$, with a relatively long half-life of 253 days, has a high $\gamma$-ray dose rate (two gammas of 880 and $660 \mathrm{KeV}$ ) (16). This poses radiation exposure problems during its transportation, handling, and refabrication. Since silver is a low melting element $\left(\sim 920^{\circ} \mathrm{C}\right)$, it can alter the microstructure of the fuel during reactor operations $\left(\sim 1600^{\circ} \mathrm{C}\right)$.

Atomic absorption spectrometry (AAS) is one of the important techniques used in all analytical laboratories working on trace metallic assay of various materials. The strong point in favor of AAS, in particular with an electrothermal atom- 
izer (ETA), is its ability to provide precise results and high sensitivity, as well as measurement using a significantly small sample size. In graphite furnace (GF) AAS, the atomizer suffers physical and chemical interferences, which include loss of volatile elements, reduced analyte volatility in the presence of a matrix, and/or a tendency for carbide formation $(17,18)$. These types of interference studies are done for geological (19) and biological samples $(20,21)$. The signal reduction in most of the cases was identified as losses during the pre-atomization stage resulting from the formation of volatile components $(18,22)$. These problems can be overcome by using chemical modifiers (18) or in situ matrix separation (23) for the determination of some analytes in soil samples. Atomic absorption spectrometry utilizing a graphite furnace as the atomizer has proven to be a very successful method for the direct determination of a number of important trace elements in nuclear material-based samples such as plutonium $(24,25)$, uranium (26) thorium (27), and zirconium (28).

The use of flame and flameless AAS is reported for silver determination in wine (29), urine (30), geological and related materials $(31,32)$, airborne particulate matter (33), lead ash and lead mud (34), biological materials (35), teeth (36), precious metals (37), blood (38), steel (39), environmental samples (40), and water samples (41).

In addition to AAS, other analytical techniques are also used to determine silver in Roman silver denarii by X-ray fluorescence and laser-induced breakdown spectroscopy analysis (42), polymeric samples by absorption, mass, and X-ray spectrometry (43), tissues using electrospray ionization tandem mass spectrometry (44), in 20 plants from the copper mining area by inductively coupled plasma mass spectrometry (45), and seawater
(46). Other techniques include sensitive sector field inductively coupled plasma mass spectrometry (SF-ICP-MS) for the analysis of cultivated Japanese and South Korean oysters and Japanese rock oysters using the 24.6-s neutron activation product ${ }^{110} \mathrm{Ag}$ (47), edible oils by inductively coupled plasma optical emission spectrometry (ICP-OES) (48), and milk by ICP-MS (49). Recently, Sengupta et. al. (50) determined trace constitutes in $\mathrm{U}-\mathrm{Zr}$ alloy after extracting $\mathrm{U}$ and $\mathrm{Zr}$, followed by the analysis of the raffinate for a few trace metallic constituents such as $\mathrm{Al}, \mathrm{B}, \mathrm{Cd}, \mathrm{Co}, \mathrm{Cr}$, $\mathrm{Cu}, \mathrm{Dy}, \mathrm{Eu}, \mathrm{Gd}, \mathrm{Fe}, \mathrm{Mn}, \mathrm{Na}, \mathrm{Ni}, \mathrm{Sm}$, and $\mathrm{Zn}$ by inductively coupled plasma atomic emission spectrometry (ICP-AES). Earlier, Huff et al. (51) attempted to determine the trace metal impurities in U-Pu-Zr alloy fuel using anion exchange partition chromatography. While there is a fairly diverse array of data on the behavior of plutonium, thorium, uranium, and zirconium matrices (24-28), no studies of a combined $(\mathrm{U}+\mathrm{Zr}$ ) system have been published using the AAS techniques.

This study focuses mainly on establishing the effect of a $(\mathrm{U}+\mathrm{Zr}$ ) matrix on the absorbance of Ag. This has also helped to understand the change in the analyte absorbance signals with a change in matrix composition of $\% \mathrm{Zr} / \mathrm{U}+\mathrm{Zr}$ and concentration of $(\mathrm{U}+\mathrm{Zr})$ in GFAAS. The enhancement was more pronounced in the presence of a high percentage of $\mathrm{Zr}$ in the $(\mathrm{U}+\mathrm{Zr})$ matrix which is due to the relative release of oxygen during dissociation of the matrices. A marginal enhancement was observed in the $(\mathrm{U}+\mathrm{Zr})$ matrix as compared to the pure uranium matrix. A comparison of the analyte atom density in pure and matrix oxides was used to understand the matrix effect on the Ag absorbance signal. These studies were then utilized for the direct determination of sub-ppm amounts

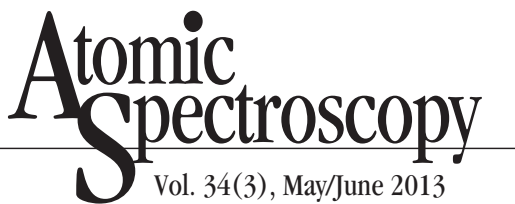

of silver in a $(\mathrm{U}+\mathrm{Zr})$ matrix with $20 \% \mathrm{Zr}$ and employing GFAAS analysis.

\section{EXPERIMENTAL}

\section{Instrumentation}

A computer-controlled GBC-906 atomic absorption spectrometer (GBC Scientific Equipment, Australia), equipped with a GF 3000 graphite furnace atomizer, was used for the determination of Ag. Details of the AAS instrument and preparation of the uranium and thorium matrix solutions were reported earlier (24). The atomizer was covered with a shield made of Perspex ${ }^{\circledR}$ material which could be displaced when access to the atomizer was necessary. Containment of the uranium-zirconium fumes was ensured through an adequate exhaust system provided around the atomizer (52). The atomizer unit exhaust was connected to a glove box exhaust system. Preparation by our laboratory of the uranium $(200 \mathrm{mg} / \mathrm{mL})$ and zirconium $(14 \mathrm{mg} / \mathrm{mL})$ solutions were reported earlier (24-28). Silver working solutions were prepared by appropriate dilution of the standard stock solutions (Ag $1 \mathrm{mg} / \mathrm{mL}$ in 5\% nitric acid; VHG Labs.). To study the matrix composition effect, a mid-range concentration standard was prepared for Ag with varying amounts of $\mathrm{Zr}$ in a (U+Zr) matrix ranging from $0-40 \%$ (zero concentration corresponds to $20 \mathrm{mg} / \mathrm{mL} \mathrm{U}$ alone). To study the matrix concentration effect, a standard of midrange concentration was prepared with varying amounts of matrix ranging from $0-40 \mathrm{mg} / \mathrm{mL}$. After optimizing the matrix proportion, a series of standard solutions were prepared with and without matrix ( $4 \mathrm{mg} / \mathrm{mL} \mathrm{Zr}, 16 \mathrm{mg} / \mathrm{mL} \mathrm{U}, 20$ $\mathrm{mg} / \mathrm{mL} \mathrm{U}$, and $20 \mathrm{mg} / \mathrm{mL} 20 \% \mathrm{Zr}+\mathrm{U}$ $(4 \mathrm{mg} / \mathrm{mL} \mathrm{Zr}+16 \mathrm{mg} / \mathrm{mL} \mathrm{U})$ and with graded concentrations of $\mathrm{Ag}$ in the range of $0-100 \mathrm{ng} / \mathrm{mL}$. In the absence of certified reference mate- 
rials with this matrix, three synthetic samples of $(\mathrm{U}+\mathrm{Zr})$ were prepared with a matrix $(20 \mathrm{mg} / \mathrm{mL}$ $20 \% \mathrm{Zr}+\mathrm{U}$, i.e., $4 \mathrm{mg} / \mathrm{mL} \mathrm{Zr}+16$ $\mathrm{mg} / \mathrm{mL} \mathrm{U}$ ) and graded concentrations of $\mathrm{Ag}$ at $0.8,1.5$, and $2.5 \mathrm{ppm}$ $(\mu \mathrm{g} / \mathrm{g})$ which is equivalent to 0.016 , 0.03 , and $0.05 \mu \mathrm{g} / \mathrm{mL}$ in $20 \mathrm{mg} / \mathrm{mL}$ of $(\mathrm{Zr}+\mathrm{U})$ matrix, respectively.

The instrumental parameters used for Ag are given in Table I. Argon gas of $99.995 \%$ purity was used as the purge gas. Using the 'dry' and 'pre-atomize' stages of the heating cycles, the rate of the purge gas was set at $6 \mathrm{~L} / \mathrm{min}$. Absorbance measurements were carried out in the 'gas stop' mode during the atomization stage.

The fundamental conditions of the GFAAS analysis (such as temperature and time durations at the pre-atomization and atomization steps) were investigated in order to identify the optimum conditions for obtaining stable and sensitive atomic absorbance signals for $\mathrm{Ag}$ in $20 \mathrm{mg} / \mathrm{mL} \mathrm{U}$ and $20 \mathrm{mg} / \mathrm{mL}$

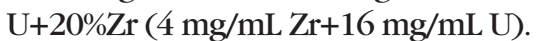
The detailed procedure adopted here was similar to that followed earlier for the trace metal analysis of $\mathrm{Ag}$ in plutonium-uranium (24). A Model M/s Reytek two-color optical pyrometer (Reytek, USA), sensitive in the $1000-3000{ }^{\circ} \mathrm{C}$ range, was used to measure the temperatures in the atomization stage. The Ag absorbance was monitored as a function of (a) matrix composition on a fixed concentration of $\mathrm{Ag}$ and

Table I

Instrumental Parameters for Ag Using the GF-3000 AAS

\begin{tabular}{ll}
\hline Wavelength & $328.1 \mathrm{~nm}$ \\
Spectral Bandwidth & $0.5 \mathrm{~nm}$ \\
Lamp Fill Gas & $\mathrm{Ne}$ \\
Lamp Current & $5 \mathrm{~mA}$ \\
Gas used & $\mathrm{Ar}$ \\
Flow rate & $6 \mathrm{~L} / \mathrm{min}^{\mathrm{a}}$
\end{tabular}

\footnotetext{
a Only during dry and pre-atomization stage.
}

varying zirconium proportions in the range $0-40 \% \mathrm{Zr}$ and (b) matrix concentration in the range of $0-40 \mathrm{mg} / \mathrm{mL}$ of $(\mathrm{U}+\mathrm{Zr})$ using fixed analyte concentrations. Characteristic concentration was obtained for Ag by analyzing four sets of standards, i.e., one each in $4 \mathrm{mg} / \mathrm{mL} \mathrm{Zr}$, $16 \mathrm{mg} / \mathrm{mL} \mathrm{U}, 20 \mathrm{mg} / \mathrm{mL} \mathrm{U}$, and $20 \mathrm{mg} / \mathrm{mL} \mathrm{U}+20 \% \mathrm{Zr}$ with a graded proportion of $\mathrm{Ag}$.

The study on the atomization of $\mathrm{Ag}$ in a matrix-free solution as well as in a $(\mathrm{U}+\mathrm{Zr})$ matrix resulted in the optimization of the pre-atomization and atomization temperature and time duration for $\mathrm{Ag}$.

The atomization mechanism for Ag atomization was studied using the absorbance-time-temperature profile of the absorbance signal. From the initial portion of the profile at various temperature points, corresponding absorbance signals were measured. From these data points, the Arrhenius plot of log absorbance vs. inverse of absolute temperature was obtained and used to calculate the activation energies $\left(\mathrm{E}_{\mathrm{a}}\right)$; signal appearance temperatures $\left(T_{\text {app }}\right)$ were obtained from the absorbance profile for matrix and matrix-free solutions. The appearance temperature is the temperature producing a just noticeable signal above the blank absorbance.

\section{RESULTS AND DISCUSSION}

In GFAAS, atomization of an analyte in the presence of a complex matrix such as $\mathrm{Pu}, \mathrm{U}, \mathrm{Zr}$, and $\mathrm{Th}$ (24-28) is the result of the interaction of analyte-matrix, analyte-carbon, or carbon-matrix. Earlier we carried out an investigation on the absorbance and atomization behavior of $\mathrm{Ag}$ in matrices such as $\mathrm{U}, \mathrm{Pu}$, $\mathrm{Th}$, and $\mathrm{U}+\mathrm{Pu}$. Inference drawn from these studies shows that the absorbance of silver is found to be different in a matrix vs. a matrixfree solution. These results propelled us to investigate similar studies in $(\mathrm{U}+\mathrm{Zr})$ matrix, a fuel proposed for fast breeder reactors.

An investigation of the GFAAS measurement parameters, such as pre-atomization temperature, atomization temperatures and time, is very important for achieving precise and sensitive atomic absorbance measurements. The pre-atomization temperature is critical in case of silver since $\mathrm{AgNO}_{3}$ dissociates to silver oxide $\left(\mathrm{Ag}_{2} \mathrm{O}\right)$ at $300{ }^{\circ} \mathrm{C}$, which decomposes immediately, and $\mathrm{Ag}$ atomization takes place at $877^{\circ} \mathrm{C}$ (53). For optimization of the GFAAS measurement parameters, the effects of the pre-atomization and atomization temperature on the absorbance were investigated using the GF 3000 graphite furnace atomizer in the temperature range of $300-700{ }^{\circ} \mathrm{C}$ for $\mathrm{Ag}$ in $20 \mathrm{mg} / \mathrm{mL}$ of uranium matrix. As seen in Table II, the $S / N$ ratio was maximum at $600^{\circ} \mathrm{C}$. The effect of the atomization temperature on the absorbance of Ag was similarly investigated over a temperature range 2100 to $2500{ }^{\circ} \mathrm{C}$. A constant and maximum absorbance was obtained at an atomization temperature of 2300 to $2400{ }^{\circ} \mathrm{C}$. Based on these observations, the pre-atomization and atomization temperatures and time durations selected for Ag by the proposed procedures were $600{ }^{\circ} \mathrm{C} / 30 \mathrm{~s}$ and $2300{ }^{\circ} \mathrm{C} / 0.3 \mathrm{~s}$, respectively. The results of the preatomization/atomization studies for uranium are listed in Table II.

\section{Effect of Matrix Composition}

Using the optimized parameters, the effect of matrix composition was studied by varying the $\mathrm{Zr}$ percentage in the $(\mathrm{U}+\mathrm{Zr}$ ) matrix from $0-40 \%$, keeping the total matrix concentration as $20 \mathrm{mg} / \mathrm{mL}$ at $0.04 \mu \mathrm{g} / \mathrm{mL}$ of $\mathrm{Ag}$. As can be seen from Figure 1a, with an increase in the $\% \mathrm{Zr} / \mathrm{U}+\mathrm{Zr}$ matrix, the $\mathrm{Ag}$ absorbance significantly increased in comparison to using a pure $\mathrm{U}$ solution $(0 \% \mathrm{Zr})$. 


\section{Atomic Spectroscopy \\ 1 Vol. 34(3), May/June 2013}

It was observed that when a new tube was used and the initial loading was conducted with $40 \%$ $\mathrm{Zr} / \mathrm{U}+\mathrm{Zr}$, the absorbance was 0.642 . Subsequent loading with a lower percentage of $\mathrm{Zr}$ decreased the signal, finally leading to a signal of 0.349 for a zero percentage of $\mathrm{Zr}$ $(100 \% \mathrm{U})$ matrix. Enhancement in absorbance with a higher \% of $\mathrm{Zr}$ results in a decrease in partial pressure of oxygen $\left(\mathrm{pO}_{2}\right)$ in the atomizer. With a decrease in $\% \mathrm{U}$, release of $(\mathrm{O})$ from the decomposition of uranyl nitrates is reduced and resulted in an increased efficiency of the atomization of silver. Thermogravimetric analysis (54) shows the decomposition of uranyl nitrate to its dioxide in the temperature ranges of $297-1297^{\circ} \mathrm{C}$ as follows:

$$
\left.\mathrm{UO}_{2}\left(\mathrm{NO}_{3}\right) 2: 6 \mathrm{H}_{2} \mathrm{O}_{(\mathrm{S})} \stackrel{297^{\circ} \mathrm{C}}{\longrightarrow} \mathrm{UO}_{3} \stackrel{757^{\circ} \mathrm{C}}{\longrightarrow} \mathrm{U}_{3} \mathrm{O}_{8} \stackrel{1(\mathrm{~s})}{\stackrel{1297^{\circ} \mathrm{C}}{\longrightarrow}} \mathrm{UO}_{2} \longrightarrow \mathrm{ss}\right) \mathrm{UC} / \mathrm{UC}_{2}(\mathrm{~s})
$$

The partial pressure of oxygen atoms released during thermogravimetric analysis according to the above equation was:

Above $297^{\circ} \mathrm{C}$ :

$$
\mathrm{UO}_{3(\mathrm{~s})} \quad \mathrm{O} / \mathrm{U} \quad 3.0
$$

Above $757^{\circ} \mathrm{C}$ :

$$
\mathrm{U}_{3} \mathrm{O}_{8(\mathrm{~s})} \quad \mathrm{O} / \mathrm{U} \quad 2.67
$$

Above $1297^{\circ} \mathrm{C}$ :

$$
\mathrm{UO}_{2(\mathrm{~s})} \quad \mathrm{O} / \mathrm{U} \quad 2.0
$$

The change in partial pressure of oxygen atoms in uranium takes place at/around the appearance temperature of $\mathrm{Ag}\left(877^{\circ} \mathrm{C}\right)(53)$, hence, the reduction of $\mathrm{Ag}_{2} \mathrm{O}$ is

TABLE II

Optimized Experimental Parameters for Ag at $0.02 \mu \mathrm{g} / \mathrm{mL}$ in U

\begin{tabular}{cccccc}
\hline \multicolumn{2}{c}{$\begin{array}{c}\text { Pre-atomization Step Temperature } \\
\text { for 30 seconds }\end{array}$} & \multicolumn{3}{c}{$\begin{array}{c}\text { Atomization Step Temperature } \\
\text { for 0.3 seconds }\end{array}$} \\
\hline Temp. ${ }^{\circ} \mathrm{C}$ & Matrix Blank & Ag Signal & Temp. ${ }^{\circ} \mathrm{C}$ & Matrix Blank & Ag Signal \\
\hline 300 & 0.008 & 0.238 & 2100 & 0.008 & 0.193 \\
400 & 0.002 & 0.246 & 2200 & 0.002 & 0.227 \\
500 & 0.002 & 0.251 & 2300 & 0.002 & 0.261 \\
600 & 0.002 & 0.256 & 2400 & 0.004 & 0.260 \\
700 & 0.004 & 0.230 & 2500 & 0.004 & 0.244 \\
\hline
\end{tabular}

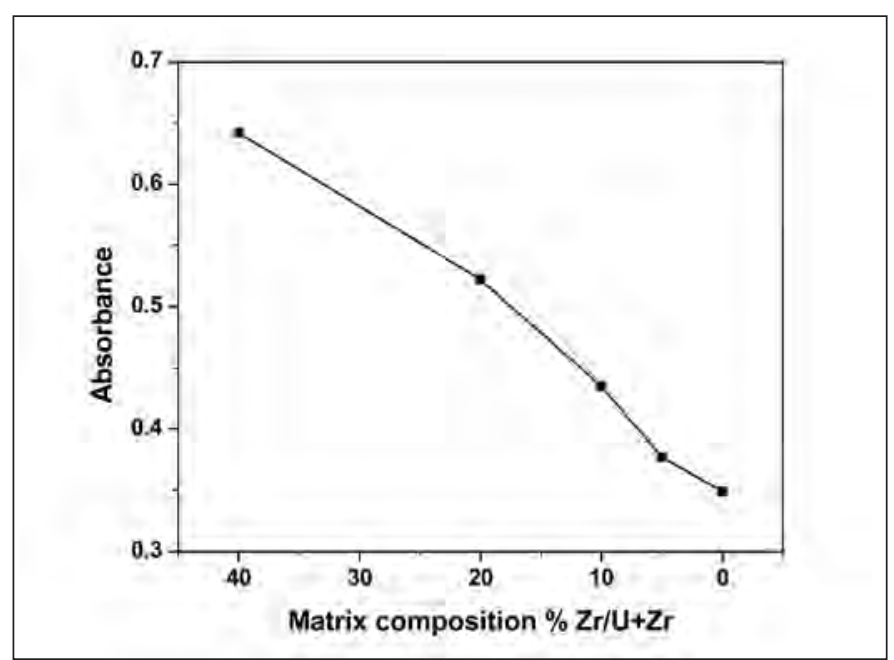

Fig. 1(a). Absorbance signal with $Z r / Z r+U$ ratio decreasing decreased quantitatively, and the absorbance is suppressed in the uranium matrix in comparison to the aqueous medium. While no such disproportionation to the release of oxygen in zirconium oxide was reported, its melting point and boiling point are higher than the Ag atomization temperature of $2700{ }^{\circ} \mathrm{C}$ and $5000{ }^{\circ} \mathrm{C}$, respectively (55).

$$
\mathrm{Zr}\left(\mathrm{NO}_{3}\right)_{4} \cdot 6 \mathrm{H}_{2} \mathrm{O}_{(\mathrm{s})} \rightarrow \mathrm{ZrO}_{2(\mathrm{~s})}
$$

In contrast, it was observed that with a new tube and initial loading conducted with zero \% Zr (100\% $\mathrm{U})$, the absorbance signal was 0.343 . In subsequent loadings with a higher percentage of $\mathrm{Zr}$, a slow increase in signal was observed (see Figure $1 \mathrm{~b}$ ), and finally led to a signal of 0.410 only for $40 \% \mathrm{Zr} / \mathrm{U}+\mathrm{Zr}$. In the former case, the increase in the absorbance signal with an increase in $\% \mathrm{Zr} / \mathrm{U}+\mathrm{Zr}$ was $50 \%$, while in the latter case with an increase in $\% \mathrm{Zr}$ the signal increased only by $20 \%$.

With uranium and zirconium, the matrix-carbon interaction competes with the analyte-carbon inter-

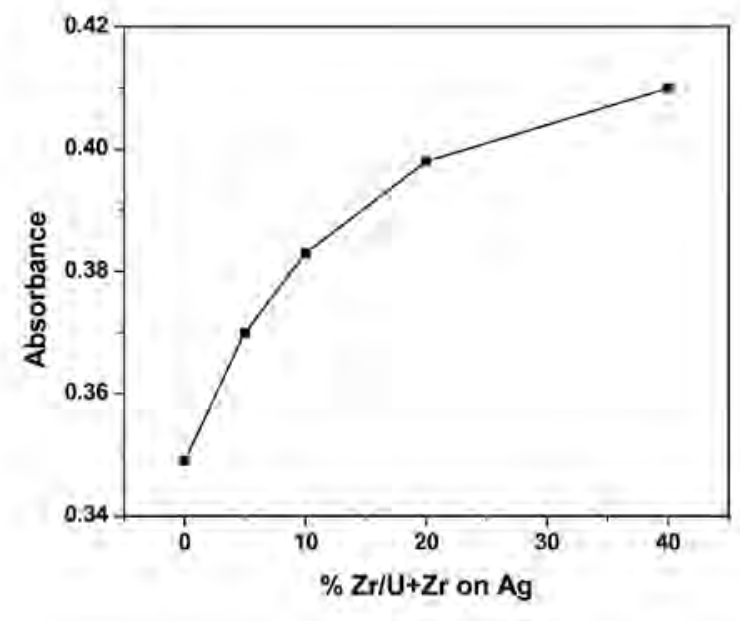

Fig. 1(b). Absorbance signal with $Z r / Z r+U$ ratio increasing. 


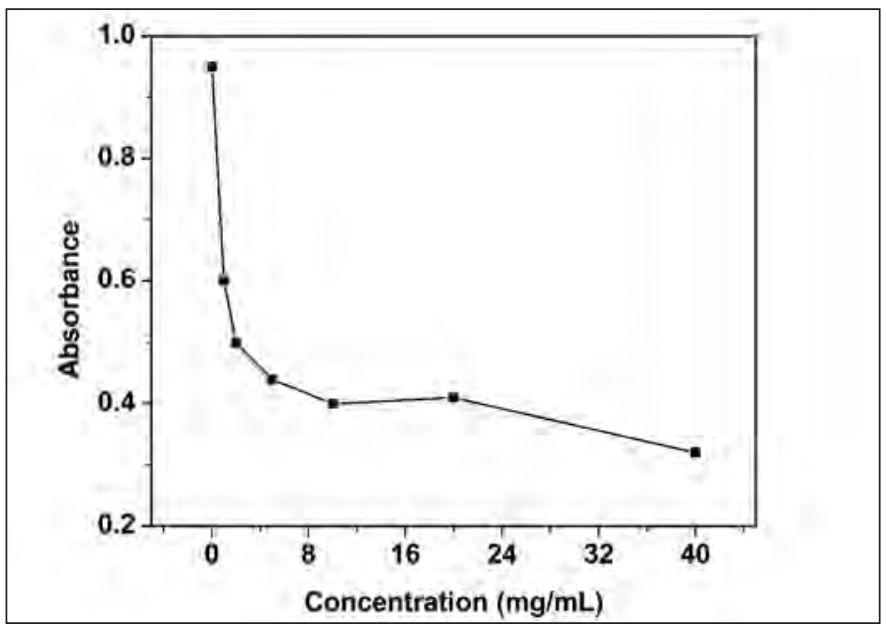

TABLE III

Optimized Experimental Parameters of GF for Ag in $(U+Z r)$ Matrix

\begin{tabular}{lrcc}
\hline $\begin{array}{l}\text { Atomizer } \\
\text { Stage }\end{array}$ & Temp. & \multicolumn{2}{c}{ Time (s) } \\
\hline Dry & 80 & 5 & 10 \\
& 120 & 10 & 10 \\
& 300 & 5 & 10 \\
Pre-atomize & 600 & 0.2 & 10 \\
Atomize & 2300 & 0.9 & 0.3 \\
Cooling & 20 & 14.5 & 10.0 \\
\hline
\end{tabular}

Fig. 2. Matrix concentration effect on $0.04 \mu \mathrm{g} / \mathrm{mL} \mathrm{Ag}$.

action as uranium and zirconium have higher carbon affinity than the analyte and preferentially forms a uniform stable $\mathrm{UC} / \mathrm{ZrC}$ or $\mathrm{UC}_{2} / \mathrm{ZrC}_{2}$ layer. With the addition of a solution having $40 \% \mathrm{Zr}$ in a $(\mathrm{U}+\mathrm{Zr})$ solution on the already formed stable $\mathrm{UC} / \mathrm{UC}_{2}$ layer in the latter case did not show as much increase in comparison to loading $40 \% \mathrm{Zr}$ in $(\mathrm{U}+\mathrm{Zr})$ on the new tube in the former case. This can be explained on the basis of uranium and zirconium chemistry. With the initial loading of $\mathrm{Ag}$ in $100 \% \mathrm{U}$, a stable lattice of $\mathrm{UC}_{2}$ is formed. The $\mathrm{UC}_{2}$ thus formed, dissolved by $0.1 \mathrm{M} \mathrm{HNO}_{3}$ of the next aliquot loading and having 5-40\% $\mathrm{Zr} / \mathrm{U}+\mathrm{Zr}$ solution, forms free uranyl nitrate $\left[\mathrm{UO}_{2}\left(\mathrm{NO}_{3}\right)_{4}\right]$ from the stable $\mathrm{UC}_{2}$ again. Hircq (56) reported the re-dissolution of $\mathrm{UC} / \mathrm{UC}_{2}$ from the next loading of the nitrate solution in the atomizer. This uranyl nitrate on dissociation gives free [O] and in turn did not show an increase in Ag absorbance in $40 \% \mathrm{Zr} / \mathrm{U}+\mathrm{Zr}$ on $100 \% \mathrm{U}$ solution on the GF atomizer as compared with $40 \% \mathrm{Zr} / \mathrm{U}+\mathrm{Zr}$ solution on the fresh GF atomizer as in the former case. This probably resulted due to the change in the ratio of $\mathrm{Zr}: \mathrm{U}:: 40: 60$ to $\mathrm{Zr:U}:$ :40-x: $60+x$. The increase in absorbance with an increase in $\mathrm{Zr}$ percentage is marred by the presence of a high concentration of $\mathrm{UC}_{2}$ in the $\mathrm{GF}$ atomizer. Dissolution of zirconia essentially requires $\mathrm{HF}$ along with $\mathrm{HNO}_{3}$. Hence, it did not dissolve in $\mathrm{HNO}_{3}$ from the next solution loading and unlike as in the U matrix, $\mathrm{Zr}$ could not add additional $\mathrm{Zr}$ content.

The influence of mixed matrices on silver atomization behavior showed that Ag sensitivity is poorer in mixed matrices in comparison to pure nitrate solutions, and changes with a change in the percentage of $\mathrm{Zr}$. It is, therefore, necessary to match the standard and sample compositions in the mixed matrix. The matrix composition used for further studies was finalized to $20 \% \mathrm{Zr} /(\mathrm{U}+\mathrm{Zr})$.

\section{Effect of Matrix Concentration}

A study on the atomization of Ag in a mixed matrix was carried out by varying the concentration of the matrix $(0-40 \mathrm{mg} / \mathrm{mL})$. The variation in absorbance signal obtained as a function of matrix concentration is shown in Figure 2.

As can be seen in Figure 2, there is a significant suppression in the absorbance signal with an increase in matrix concentration up to $5 \mathrm{mg} / \mathrm{mL}$, followed by a marginal suppression up to $20 \mathrm{mg} / \mathrm{mL}$. The mechanism of release of gaseous atoms from the solid lattice in GFAAS has been investigated by thermodynamic-kinetic approaches (57). It was noted that though the nitrate solution of either Ag alone or with $(\mathrm{U}+\mathrm{Zr})$ is loaded, nitrates get converted to oxides of Ag or oxides of $\mathrm{U}$ and $\mathrm{Zr}$. Silver has to be released from the stable lattices of $\mathrm{U}$ and $\mathrm{Zr}$ oxides. Hence, with an increase in matrix concentration, the release of $\mathrm{Ag}$ atoms is reduced and causes suppression in $\mathrm{Ag}$ absorbance.

Using a higher matrix concentration, i.e., $20 \mathrm{mg} / \mathrm{mL}$ instead of $5 \mathrm{mg} / \mathrm{mL}$, is always preferred since it provides better detection limits (in ppm instead of $\mu \mathrm{g} / \mathrm{g}$ ). Thus, for further studies, a $20 \mathrm{mg} / \mathrm{mL}$ concentration of Ag was used. The experimental parameters were optimized with $20 \% \mathrm{Zr} / \mathrm{U}+\mathrm{Zr}$ at a $20-\mathrm{mg} / \mathrm{mL}$ concentration and are listed in Table III.

Using freshly optimized parameters with the $(\mathrm{U}+\mathrm{Zr})$ solution, a method was developed for the direct determination of $\mathrm{Ag}$ in a $20 \mathrm{mg} / \mathrm{mL}$ of $\mathrm{U}+20 \% \mathrm{Zr}$ matrix using the $328.1 \mathrm{~nm}$ spectral line. Measurement of the atomic absorption signals for Ag was carried out over a wide range of concentrations using standard solutions in these matrices. The linear analytical ranges in 


\section{Atomic Apectroscopy \\ $\bigcirc$ Vol. 34(3), May/June 2013}

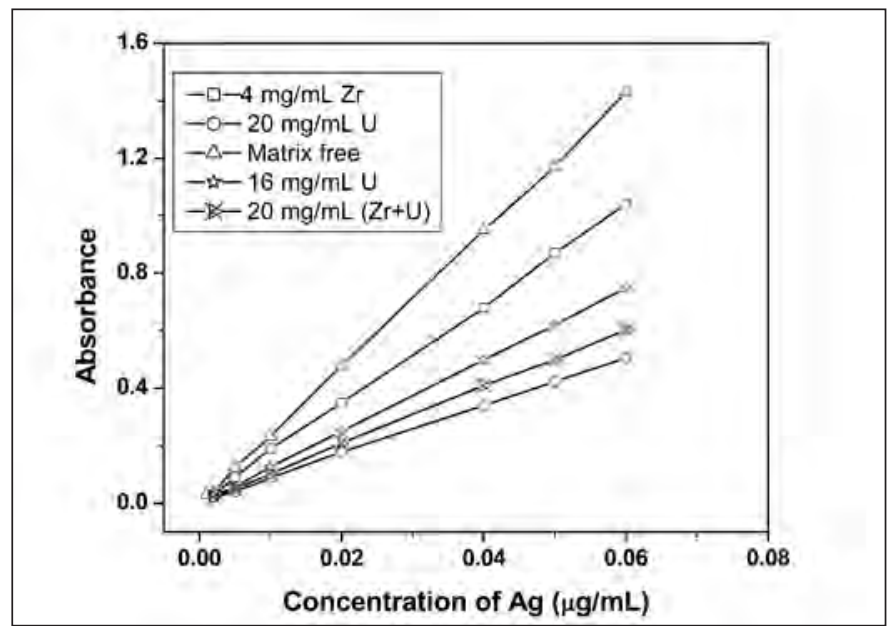

Fig. 3. Analytical curves for Ag in aqueous, $4 \mathrm{mg} / \mathrm{mL} \mathrm{Zr}$, $16 \mathrm{mg} / \mathrm{mL} \mathrm{U}, 20 \mathrm{mg} / \mathrm{mL} \mathrm{U}$, and $20 \mathrm{mg} / \mathrm{mL}(20 \% \mathrm{Zr} / U+Z r)$.

TABLE IV

Characteristic Concentrations (C.C.), Smallest Amount Determined, and Range of Analysis

\begin{tabular}{llllll}
\hline Matrix & $\begin{array}{c}\text { C.C. } \\
(\mathrm{ng} / \mathrm{mL})\end{array}$ & \multicolumn{2}{c}{ Linear Analytical Range } \\
$(\mu \mathrm{g} / \mathrm{mL})$ & $\begin{array}{c}\text { LOQD }(\mathrm{g}) \\
(\mu \mathrm{g} / \mathrm{g})\end{array}$ & Present & $\begin{array}{c}\text { Reported } \\
(2)\end{array}$ \\
\hline Aqueous & 0.2 & $0.001-0.06$ & - & $0.5 \times 10^{-12}$ & $0.5 \times 10^{-12}$ \\
$4 \mathrm{mg} / \mathrm{mL} \mathrm{Zr}$ & 0.25 & $0.002-0.06$ & $0.5-15.0^{\mathrm{a}}$ & $1 \times 10^{-12}$ & - \\
$16 \mathrm{mg} / \mathrm{mL} \mathrm{U}$ & 0.35 & $0.002-0.06$ & $0.125-3.75^{\mathrm{b}}$ & $1 \times 10^{-12}$ & - \\
$20 \mathrm{mg} / \mathrm{mL} \mathrm{U}$ & 0.5 & $0.002-0.06$ & $0.1-3.0^{\mathrm{c}}$ & $1 \times 10^{-12}$ & $1 \times 10^{-12}$ \\
$20 \mathrm{mg} / \mathrm{mL}(\mathrm{U}+\mathrm{Zr})$ & 0.45 & $0.002-0.06$ & $0.1-3.0^{\mathrm{c}}$ & $1 \times 10^{-12}$ & - \\
\hline
\end{tabular}

${ }^{\mathrm{a}}$ Based on $20 \mu \mathrm{g}$ of $\mathrm{Zr},{ }^{\mathrm{b}}$ based on $80 \mu \mathrm{g}$ of $\mathrm{U}$, and ${ }^{\mathrm{c}}$ based on $100 \mu \mathrm{g} \mathrm{U} / \mathrm{U}+\mathrm{Zr}$ in $5 \mu \mathrm{L}$ of solution.

TABLE V

Calculated Area Under Profiles, Time to Reach Peak, Profiles Width and Height

\begin{tabular}{clcccc}
\hline Sample No. & Matrix & Area & Peak at $(\mathrm{ms})$ & Width & Height \\
\hline 2 & Matrix-free & 162.18 & 300 & 250 & 0.527 \\
1 & $16 \mathrm{mg} / \mathrm{mL} \mathrm{U}$ & 152.06 & 425 & 500 & 0.3 \\
3 & $4 \mathrm{mg} / \mathrm{mL} \mathrm{Zr}$ & 154.41 & 325 & 425 & 0.35 \\
4 & $20 \mathrm{mg} / \mathrm{mL} \mathrm{U}$ & 96.36 & 425 & 400 & 0.22 \\
5 & $20 \mathrm{mg} / \mathrm{mL} \mathrm{U}+\mathrm{Zr}$ & 103.1 & 400 & 375 & 0.259 \\
\hline
\end{tabular}

the presence and absence of matrices were obtained. Characteristic concentrations (C.C.), the smallest amount determined and the range of the analysis in the presence and absence of matrix, are listed in Table IV. The working linear analyt- ical curves for $4 \mathrm{mg} / \mathrm{mL} \mathrm{Zr}$, $16 \mathrm{mg} / \mathrm{mL} \mathrm{U}, 20 \mathrm{mg} / \mathrm{mL} \mathrm{U}$, and $20 \mathrm{mg} / \mathrm{mL}(20 \% \mathrm{Zr} / \mathrm{U}+\mathrm{Zr})$ along with a matrix-free solution are shown in Figure 3. As seen from Figure 3 and Table IV, the analytical range and sensitivity of the method- ology is poorer in the matrix vs. the matrix-free solution.

Figure 4 shows the peak profiles plotted at $0.02 \mu \mathrm{g} / \mathrm{mL} \mathrm{Ag}$ in the absence and presence of the matrices $(4 \mathrm{mg} / \mathrm{mL} \mathrm{Zr}, 16 \mathrm{mg} / \mathrm{mL} \mathrm{U}$, $20 \mathrm{mg} / \mathrm{mL} \mathrm{U}$, and $20 \mathrm{mg} / \mathrm{mL}$ $20 \% \mathrm{Zr}+\mathrm{U}$. The area under profiles, time to reach peak, profiles width and height were calculated from the curves and are listed in Table V. It was observed that the peak profile broadened and the peak height area reduced in the presence of the matrices. An increase in peak width can be attributed to slow analyte release. This indicates that the matrix plays a major role in signal suppression. The stable lattice and the closed packed face centered cubic structure of urania and zirconia acts as an entrapment for the Ag atoms, resulting in suppression of the Ag absorbance signal in the matrix.

Successive loadings of the $(\mathrm{U}+\mathrm{Zr}$ ) solution led to matrix buildup inside the graphite atomizer. However, this buildup of matrix did not have any significant effect on the $\mathrm{Ag}(0.04 \mu \mathrm{g} / \mathrm{mL})$ absorbance with repetitive loading of the $20.0 \mathrm{mg} / \mathrm{mL}$ mixed matrix on the same atomizer. The absorbance remained constant with repetitive 
loading of the sample up to 100 atomization cycles.

The performance of the above method was evaluated by analyzing synthetic samples containing $\mathrm{Ag}$ in $20 \% \mathrm{Zr}+80 \% \mathrm{U}$. Using the standardized procedure, three synthetic samples were analyzed. The results obtained from the analysis of these synthetic samples are listed in Table VI. A comparison of these results based on 8-10 replicate measurements indicates close agreement for all of the determinations. The replicate analyses of the synthetic samples showed the precision of the method to be better than $8 \%$ RSD.

\section{CONCLUSION}

This study shows that an increase in absorbance of $\mathrm{Ag}$ was observed with an increase in $\mathrm{Zr}$ content in a $(\mathrm{U}+\mathrm{Zr})$ matrix, whereas a significant suppression in the absorbance of Ag was observed with an increase in matrix concentration. Since zirconia and urania are refractory in nature, their lattices affect the Ag atomization. The GFAAS method described here can be applied to direct determination of sub-ppm levels of $\mathrm{Ag}$ in a $(\mathrm{U}+\mathrm{Zr}$ ) matrix containing $20 \% \mathrm{Zr}$, resulting in a relative precision of $\pm 10 \%$.

\section{ACKNOWLEDGMENT}

The authors are grateful to Dr. Ashok Goswami, Head, Radiochemistry Division, for his keen interest and constant encouragement during the course of this work.

$\overline{\text { Received January 17, } 2013 .}$

TABLE VI

Results of Analysis of Synthetically Prepared Samples for the Determination of $\mathrm{Ag}$ at $\mathrm{ppm}$

\begin{tabular}{ccccc}
\hline Sample No. & \multicolumn{2}{c}{$\begin{array}{c}\text { Concentration of Spike }(\mathrm{ppm}) \\
\text { Odded }\end{array}$} & \multicolumn{2}{c}{ RSD(\%) } \\
\hline 1. & 0.8 & 0.77 & 0.775 & 8 \\
2. & 1.5 & 1.51 & 1.45 & 7 \\
3. & 2.5 & 2.34 & 2.35 & 4 \\
\hline
\end{tabular}

\section{REFERENCES}

1. A.G. Hins, D.A. Kraft, and H.F Jelinek, Trans. Amer. Nucl. Soc. 30, 310 (1978).

2. L. Leibowitz, , E. Veleckis, R.A. Blomquist, and A.D.Pelton, J. Nucl. Mater. 154(1), 145 (1988).

3. C.E. Lahm, D.L. Porter, and R.G. Pahl, J. Metals 40(7), A86 (1988).

4. G.L. Hofman, P R. Gahl, C.E. Lahm, and D.L. Porter, J. Metals, 40(7), A86 (1988).

5. R.G. Pahl, C.E. Lahm, D.L. Porter, and G.L. Hofman, J. Metals 40(7), A71 (1988).

6. R.I. Sheldon and D.E. Peterson, Bull. Alloy Phase Diagrams 10(2), 165 ( 1989).

7. D.E. Peterson and E.M. Foltyn, Bull. Alloy Phase Diagrams 10(2), 160 (1989).

8. W.G. Steele, A.R. Wazzan, and D. Okrent, Nucl. Eng. Des. 113(3), 289 (1989).

9. D.L. Porter, C.E. Lahm, and R.G. Pahl, Metall. Trans. A, 21(7), 1871 (1990).

10. R.G. Pahl, D.L. Porter, C.E. Lahm, and G.L. Hofman, Metall. Trans. A 21(7), 1863,(1990).

11. L. Gerard, G.L. Hofman, R.G. Pahl, C.E. Lahm, and D.L. Porter, Metall. Trans. A 21(3), 517(1990).

12. M. Kurata, Calphad. 23(3-4), 305 (1999).

13. Byoung Ooon Lee et al. Proceedings of the International conference on Fat Reactors and related fuel cycles: Challenges and oppurtunities FR09 held in Kyoto, Japan during 7-11 Dec 2009, IAEA.

14. W.L. Gong, W. Lutze, and R.C. Ewing, J. Nucl. Mater 277, 239 (2000).
15. Gini Curran, Y. Sevestre, Wendy Rattray, Patrick Allen, and K.R. Czerwinski, J. Nucl. Mater. 323, 41 (2003)

16. E. Friedland, N.G. van der Berg, J.B. Malherbe, J.J. Hancke, J. Barry, E. Wendler and W. Wesch, J. of Nucl. Mat. 410, 24 (2011).

17. Jiř̌i Dědina, Spectrochim. Acta 62B, 846 (2007).

18. D.L. Tsalev, V.I. Slaveykova and P.B. Mandjukov, Spectrochim. Acta Rev. 13, 225 (1990).

19. Chai Xin-Na, Shuai Qin, Lu Ai-Min, Yao Qiu-Yue, and Liu Xian-Guo, Spectrosc. and Spectral Analysis 28, 1406 (2008)

20. G. Yang, F. Weibo, Chun Lei, W. Xiao, and S. Handong, J. Hazardous Mat. 162, 44 (2009).

21. J. Sardans, F. Montes, and J. Peñuelas, Spectrochim. Acta, 65B, 97 (2010).

22. J.Y. Cabon, Talanta 65, 402 (2005).

23. Peter Török and M. Žemberyová, Spectrochim. Acta 66B, 93 (2011).

24. Neelam Goyal, P.J. Purohit, Santosh Kumar Gupta, and S.V. Godbole, At. Spectrosc. 32(5) 206 (2011).

25. Neelam Goyal, Renu Agarwal, Paru J. Purohit, and S. V. Godbole, J. Nucl. Mat. 376119 (2008).

26. Neelam Goyal, P.J. Purohit, A.R. Dhobale, B.M. Patel, A.G. Page, and M.D. Sastry, J. Anal. At. Spectrom. 2, 459 (1987).

27. Paru J. Purohit, Neelam Goyal, and S.V.Godbole, At. Spectrosc. 32, 68 (2011).

28. Paru J. Purohit, Neelam Goyal, and S.V.Godbole, At. Spectrosc. 33, 100 (2012). 


\section{A $_{\text {Spectroscopy }}^{\text {tomic }}$ \\ 1 Vol. 34(3), May/June 2013}

29. S.L.C. Ferreira, A.S. Souza, G.C. Brandao, H.S. Ferreira, W.N.L.S. dos Santos, M.F. Pimentel, and M.G.R. Vale, Talanta 74(4), 699 (2008).

30. J. Flanjak and A.E. Hodda, Anal. Chim. Acta 207, 283 (1988).

31. P. Liang, L. Zhang, and E. Zhao, Talanta 82(3), 993 (2010).

32. I. Urbanova, L. Husakova, and J. Sramkova, Environmental Monitoring and Assessment, 1 (2012).

33. R.G.O. Araujo, F. Vignola, I.N.B. Castilho, B. Welz, M.G R. Vale, P. Smichowski, S.L.C. Ferreira, and H. Becker-Ross, Microchem. Journal 109, 36 (2012).

34. G.Q. Zuo, X. Lu, Q.p-M. Li, and Y.$\mathrm{X}$. Xu, Yejin Fenxi/Metallurgical Analysis 32(6), 43 (2012).

35. F. Gerondi and M.A.Z. Arruda, Talanta 97, 395 (2012).

36. M. Saber-Tehrani, M.H. Gvianrad, P. Kahkashan, Biol. Trace Element Res. 116(2), 155 (2007).

37. B. Salih, O. Celikbicak, S. Doker, and M. Dogan, Anal. Chim. Acta 587(2), 272 (2007).

38. P.R.M. Correia, P.V. Oliveira, J.A.G. Neto, and J.A. Nobrega, J. Anal. At. Spectrom. 19(7), 917 (2004).

39. A. Matsumoto, T. Nakahara, and Tetsu-To-Hagane, J. of the Iron and Steel Institute of Japan 92(5), 69 (2005).

40. M.A. Rahman, S. Kaneco, Md.N. Amin, T. Suzuki, and K. Ohta, Talanta 62(5), 1047 (2004).

41. H. Tavallali and A.M. Attaran, Internatl. J. of ChemTech Res. 2(3), 1724 (2010.

42. L. Pardini, A. El Hassan, M. Ferretti, A. Foresta, S. Legnaioli, G. Lorenzetti, E. Nebbia, and V. Palleschi, Spectrochim. Acta, Part B, At. Spectrosc. 74, 156 (2012).

43. I. De Schrijver, M. Aramendia, L. Vincze, M. Resano, A. Dumoulin, and F. Vanhaecke, Spectrochim. Acta, Part B, At. Spectros. 62(11), 1185 (2007).
44. K. Minakata, I. Yamagishi, H. Nozawa, K. Gonmori, K. Hasegawa, M. Suzuki, F. Horio, and O. Suzuki, Forensic Toxicology 30(2), 149 (2012).

45. Y.-H. Shi, Z.-P. Yang, C.-A. Song, L. Qiu, and S.-H. Hu, Guang Pu Xue Yu Guang Pu Fen Xi/Spectrosc. and Spectral Anal. 32(5), 1387 (2012).

46. J.L. Barriada, A.D. Tappin, E.H. Evans, and E.P. Achterberg, TrAC Trends in Anal. Chem. 26(8), 809 (2007).

47. M. Fukushima and A. Chatt, J. of Radioanal. and Nucl. Chem. 294, 471 (2012).

48. A.N. Anthemidis and V. Arvanitidis, J.A. Stratis, Anal. Chim. Acta 537, 271 (2005).

49. P. Cava-Montesinos, M.L. Cervera, A. Pastor, and M. De La Guardia, Anal. Chim. Acta 531, 111 (2005).

50. A. Sengupta, B. Rajeshwari, R.M. Kadam, and S.V. Godbole, At. Spectrosc. 33, 48 (2012).

51. E.A. Huff and S.J. Kulpa, Anal. Chem. 38(7), 939 (1966).

52. Neelam Goyal, P.J. Purohit, and S.V. Godbole, At. Spectrosc. 31, 195 (2010).

53. W.C. Compbell and J.M. Ottaway, Talanta 21, 837 (1974).

54. C. Duval, Inorganic Thermogravimetric Analysis, Elsevier, New York, NY, USA, pp. 666 (1963).

55. CRC Handbook of chemistry and Physics, Ed. R.C. Weats, Chemical Rubber Company, Ohio, USA, Bp156 (1971-72).

56. B. Hireq, Spec. Chim. Acta 31(B), 153 (1976).

57. S.B. Chang and C.L. Chakrabarti, Prog. Anal. At. Spectrosc. 8, 102 (1985) and reference therein. 